\title{
Sport Logistics Research: Reviewing and Line Marking of a New Field
}

\begin{abstract}
Purpose: Although logistics management is a crucial part of local and global sports events, there is no research-driven characterization of 'sports logistics management'. In this article, we conceptualize a framework that allows for a more structured recognition of logistics in sports in general and sport event management in particular. In addition, we conduct a systematic literature review of sports logistics management and locate opportunities for future research both for sports management and logistics management scholars.
\end{abstract}

Design/methodology/approach: Guided by Durach et al.’s (2017) systematic literature review approach, we identify key attributes and characteristics of sports logistics management. These are based on studies featuring at least partial aspects of logistics management in sports and sport events, and that were published between 2000 and mid-2019.

Findings: Our study reveals that sports logistics management - meaning logistics activities in sports and sport event management - is a heavily under-researched area that provides an abundance of scientific opportunities. Based on the three sport event types of local/regional sport events, major sport events, and mega sport events, we propose four sports logistics management pillars that are central to the proposed Sport Logistics Framework (SLF): venue logistics management, sports equipment logistics management, athletes logistics management, and fan and spectators logistics management.

Practical implications: By providing a conceptual framework for sports logistics, we progress towards informing the sport sector on relevant strategic and operational levels of logistics management and set the stage for empirical studies that are likely to advance sport logistics planning and management.

Originality/value: This is the first study that builds on a systematic review of literature specifically focused on the logistics aspect in sports and sport event management. It provides a conceptual framework of sports logistics management and offers an agenda of future research opportunities.

Keywords: sports logistics, sports management, sports events, event logistics, conceptual framework, systematic literature review, research agenda 


\section{Introduction}

The global sports market is not only a highly emotional and competitive space, but is also an industry with prolific business growth in recent years. The global sports market, comprising sports infrastructure, sports events, sports hospitality, training, and manufacturing and retail of sports goods, is estimated to be worth around US\$ 600-700 billion, representing one per cent of global GDP (KMPG, 2016). Sports events alone have a market size of US\$ 80 billion and have experienced significant growth of six per cent per year, outpacing the GDP growth in nearly every country (Collignon and Sultan, 2014). Mega sports events, such as the Olympic Games or FIFA World Cup, are today regarded to be the greatest, non-defence related, worldwide logistics operations (Minis, Paraschi, et al., 2006). For example, in the 16 days of the of Rio de Janeiro 2016 Olympic Games in Brazil, more than 11000 athletes competing in 42 sports participated in 306 events across 37 venues, involving more than 36000 volunteers from 161 countries and 6.2 million spectators (IOC, 2017; Settimi, 2016).

In order to organize both periodic and recurring sport events and competitions, managers are confronted with significant logistics challenges, with operations occurring at different levels and often in parallel. However, although sport and sport events have become an increasingly prevalent research topic in the management discipline, researchers have been very shy to acknowledge the area of logistics management and its strategic relevance; in fact, so far there has been no concentrated effort in outlining a sport logistics research agenda. Also popular textbooks and publications framed by a marketing-management-approach with its x-number of Ps only briefly touch upon supply chain management or logistics management, usually by rather nonchalant describing or summarizing it as aspects of 'planning', 'place'/distribution or 'promotion'/product management, but without presenting specific frameworks or research (see e.g. Masterman, 2014; Parent and Chappelet, 2017; Schwarz et al., 2013). Equally, latest research volumes on sport and mega event management lack any form of adequate or systematic discussion on the topic (Frawley and Adair, 2014; Schulenkorf and Frawley, 2016; Schwarz et al., 2017).

The absence of engagement with logistical aspects of management is particularly surprising given the fact that sport events and competitions are at the very core of almost the entire value creation of the professional and amateur sports sector. In particular, sports managers implement and rely on sophisticated logistics management practices as a central element in today's increasingly competitive sport business - the transport of the race cars in the Formula 1 circuit (Jenkins et al., 2016); spectators' mobility at sport community events and related festivals (Bull and Lovell, 2007; Rofe and Woosnam, 2016); or the management of permanent and temporary infrastructure around mega events (Frawley et al., 2016) offer some prominent illustration.

Overall, it appears that sport management can still learn from research conducted in related management areas, where the consideration of logistics capabilities as strategic resources for industry-specific competitive advantage has been well-documented in recent decades (see e.g. Christopher and Peck, 1997, on the fashion industry; Dubois et al., 2019, on the construction industry; Gimenez, 2006, on the food industry; see Morash et al., 1996).

With sports logistics being a field in its infancy, this contribution offers new conceptual insights and a systematic literature review that synthesizes the research that has been published to date. In particular, the aim of this paper is threefold. First, we review the scope and characteristics of sport logistics and logistics management and provide a working 
definition of sport logistics management. Second, we propose and explain the new Sports Logistics Framework (SLF) that is based on central aspects and characteristics of logistics, event and sport management literature. And third, against the background of the SLF, we undertake a systematic literature review to analyze and synthesize existing sports logistics management research, and to highlight future research directions that will prompt further debate and investigation into this important yet neglected field of study. As such, we argue that our study helps to provide a wealth of opportunities for logistics and sports management researchers in advancing state-of-the-art scholarship in this critical space; and to better understand processes and disseminate the knowledge between (logistics) managers and academics.

The remaining paper is structured as follows: In the next section, the scope and characteristics of sports logistics are identified and key elements of the newly proposed SLF are outlined. This is followed by the description of the methodological research design used to perform our systematic literature review. Next, the main findings from the review are presented by synthesizing the literature on sport logistics and highlighting key outcomes. Finally, a research agenda is proposed which is built on current gaps in the literature and proposed directions for future research.

\section{Scope and characteristics of sports logistics}

Elements of logistics management in the context of sport are predominantly mentioned in conjunction with the field of event management (Aicher et al., 2019; Allen et al., 2011; Greenwell et al., 2014; S. A. Hall et al., 2010) and can thus be regarded as a sub-function of sports event management. As such, the event management literature categorises events in three categories: mega events, major events and local or regional events (Bowdin et al., 2012; Emery, 2010) which has relevance for our discussions on sports logistics.

A sports mega event, such as Olympic Games or the FIFA World Cup, can be defined by extraordinarily high levels of tourism, global media coverage, prestige and its economic impact for the host country or community which may include significant construction of facilities and infrastructure specifically for this event (Allen et al., 2011). A major sports event, such as Formula 1 races or PGA golf events, can be defined by a strong public interest linked to international reputation, significant international media coverage, attracting large numbers of visitors including international audiences as well as international participants with a defined structure of competition (Aicher et al., 2019; Jones, 2012). Finally, regional/local sports events can be defined by their focus on local talent and audiences, and predominantly contributing to the community or town through social, fun and entertainment value (Bowdin et al., 2012; Oklobžija, 2015).

Building on the three event categorisations mentioned above, we will now engage in discussing the key event characteristics and logistical pillars and activities that are central to our newly proposed SLF framework. This discussion will lead to our working definition of sports logistics management in the context of events, and it will prepare us for the subsequent literature review for which the SLF presents the conceptual background.

\section{Event characteristics}


The three event categories regional/local sport events, major sport events and mega sport events have distinct characteristics that allow us to differentiate them. In particular, existing sport event management literature (e.g. Kauppi et al., 2013; Minis, Paraschi, et al., 2006) has identified six characteristics which have a direct impact on the respective events and the associated logistics activities, namely infrastructure, location, staff mix, audience, size and time/duration (see Table 1):

Table 1: Sports event characteristics in logistics management

\begin{tabular}{|c|c|c|c|c|c|c|}
\hline Sports event & $\begin{array}{c}\text { Infra- } \\
\text { structure }\end{array}$ & Location & Staff & Audience & Size & $\begin{array}{c}\text { Time/ } \\
\text { Duration }\end{array}$ \\
\hline $\begin{array}{l}\text { Regional/ } \\
\text { local sports } \\
\text { event }\end{array}$ & Existing & Permanent & $\begin{array}{c}\text { Majority } \\
\text { experienced }\end{array}$ & $\begin{array}{c}\text { Majority } \\
\text { local }\end{array}$ & Small & $\begin{array}{l}\text { Regular/ } \\
\text { seasonal }\end{array}$ \\
\hline $\begin{array}{l}\text { Major sports } \\
\text { event }\end{array}$ & Recurring & Recurring & $\begin{array}{c}\text { Majority } \\
\text { experienced, but } \\
\text { including share }\end{array}$ & $\begin{array}{l}\text { Mix local } \\
\text { and } \\
\text { global }\end{array}$ & Large & Frequently \\
\hline $\begin{array}{l}\text { Mega sports } \\
\text { event }\end{array}$ & $\begin{array}{l}\text { To be } \\
\text { developed/ } \\
\text { Existing }\end{array}$ & Changing & $\begin{array}{l}\text { experienced } \\
\text { Mega-event: } \\
\text { experienced-non- } \\
\text { experienced ratio } \\
\text { up to } 1: 1\end{array}$ & $\begin{array}{l}\text { Majority } \\
\text { global }\end{array}$ & Massive & Transient \\
\hline
\end{tabular}

Infrastructure: From a logistics perspective, infrastructure for sports events comprises three areas: a) the availability of appropriate warehousing space and transportation resources (appropriate space at the venues, material handling equipment, information technology, etc.), b) the host country/city/venue's logistics know-how and c) the transport infrastructure for fans and spectators to reach the venue destination (Minis, Paraschi, et al., 2006); and d) capacity for broadcasting and media, a particular main aspect of (elite) sport events. Depending on the type of sports events, infrastructure can either be existing (e.g. for seasonal soccer games), recurring (e.g. for tournaments such as the Formula 1) or need to be developed (e.g. for Olympic games).

Location: The location of a sport event affects the way the resources - including material and humans - reach the respective venue. At local sports events, the venue usually is permanent, however, certain exceptions exist such as relocations of NFL sports teams where the venue is sometimes subject to change. For major events such as tournaments, the venue usually has a permeant location, but needs to be redesigned and managed every time an event occurs. For mega events such as the Football World Cup or the Olympic Games, the location is changing every four years, which leads to its own logistical challenges (Minis, Paraschi, et al., 2006). For mega-events, the location for example affects freight forwarding operations, customs clearance and security screening processes at the gateways, as well as the lead times in different geographical contexts (Minis, Paraschi, et al., 2006).

Staff mix: Sports event experiences are delivered by staff which can, depending on the type and size of the event, vary significantly regarding experience and availability (Robinson et al., 
2010). While for local sports events as well as for seasonal major events staff capacity, training and readiness is existing or already calculated, staff at mega-events such as the Olympic Games consists of a mix of casuals and volunteers, most newly hired and inexperienced. As such, in an Olympic logistics context, a human resource ratio 1:1 of professional staff-to-volunteers is not unusual (Kauppi et al., 2013).

Audience: The audience at a sport event can range from exclusively local residents or communities to global audiences (Heere et al., 2019). In general, local sport events attract a predominantly local audience, while major and mega sport events extend to regional, national and even global audiences. As such, an international audience usually indicates higher reputation of the event, leading not only to additional ticket sales, but also to an increase in media coverage (Aicher et al., 2019; Allen et al., 2011).

Size: The size of a sports event is important indicator not only to differentiate between the three types of sport events (see above), but it has also significant implications on the logistics planning. The greater the size of a sports event, the greater the need for early capacity and material planning (Minis, Paraschi, et al., 2006).

Time/duration: The time and duration of sport events also has implications on the logistics planning. While local and some major events have regular or seasonal occurrences (with regular and seasonal staff and existing resources), mega-events have a transient nature, which leads to long planning periods of up to 10 years. This leads to substantial logistics planning and implementation that takes place well prior to the Games, and an extension of activities several months beyond the closure of the Games. Thus, the entire process turns into a complex long-term transitory operation with no steady state processes (Kauppi et al., 2013).

\section{Sports Logistics Pillars}

In addition to the previously discussed event typologies and characteristics, four distinct but interrelated sport logistics pillars form a central part of our newly designed conceptual framework. They will now be outlined and discussed in detail. As such - and together with distinct logistics activities that will be discussed in the next section - they form the managerial underpinning of the SLF (see Figure 1). 


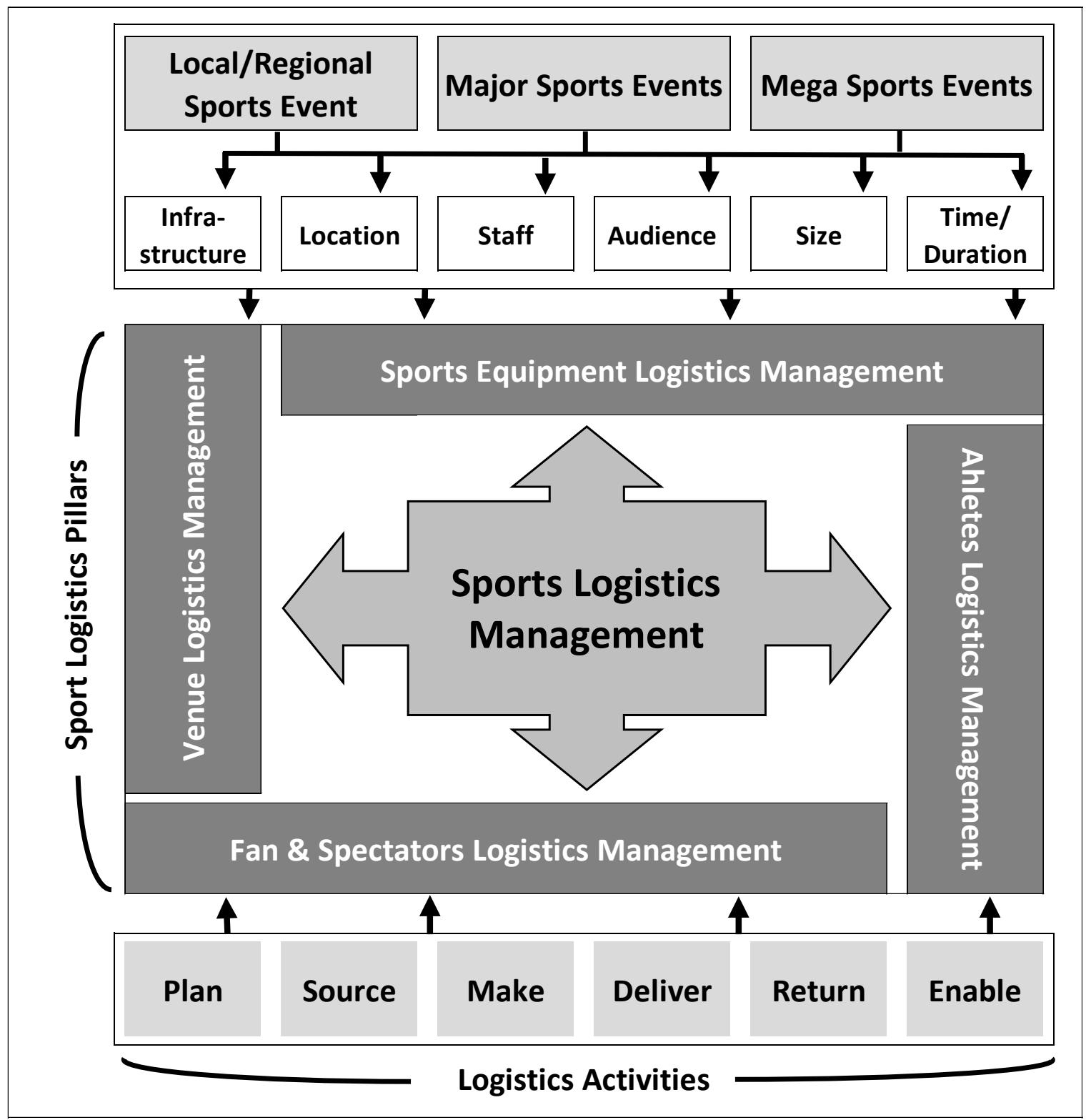

Figure 1: The Sports Logistics Framework (SLF)

First, venue logistics management is considered one of the key pillars for sport events. At major or mega events in particular, logistics is a significant part of venue operations, as these events are not only characterized by an extraordinary volume of demand for services to be provided in a very short period of time, but also because they require a large variety of services to support the many different customer groups and their specific demands (Beis et al., 2006; Robinson et al., 2010). In addition, Minis, Paraschi, et al. (2006) emphasise the importance of the resource planning for venue logistics at mega events as it may involve not only paid staff and experts, but also volunteers to fulfil the planning, implementation and management of the logistics activities.

Second, existing and to be developed infrastructure and transportation systems for fans and spectators can also be considered a key pillar for sports logistics management. While regional and more static major events often have established structures to manage fans and spectators, the transportation at mega events is a considerable challenge for sports logistics managers. 
For instance, Bovy (2003) outlines the unusual magnitude and volume of fans at a specific time and the spatial concentration of traffic flows as key challenges in this context. Hence, sports logistics managers need to align with organisers and public authorities to develop suitable, safe and often creative temporary transport and traffic management solutions. Furthermore, the implications of building infrastructure are often significant and long-lasting; as such, legacy planning should also be considered in the strategic logistics planning process (Preuss, 2007; Sant and Mason, 2015).

Third, the logistics management of athletes is another pillar of sports logistics management. While it has similarities to event management, the scope of sports logistics may go beyond the requirements for sport events. For example, optimising the schedule for the frequent travel of professional sports team may be out of the scope for sport events, but it is a key aspect for teams to perform effectively on the field. For professional basketball players in the US, for example, having 82 games in the regular season, which equals to slightly over three games a week in potentially four time-zones, a non-optimised travel schedule may affect the winningpercentages and the performance of players in the match (Huyghe et al., 2018; Roy and Forest, 2018).

The final key pillar for sports logistics managers reflects the classical tasks of logistics services: the transportation process of the required equipment for athletes, venues and fans. This includes not only the freight forwarding and the customs clearances of the required goods, but also the organisation of warehouses and the associated distribution (Minis and Tsamboulas, 2008). These logistics operations may have - in the context of the Olympic Games - a considerable volume including the transportation of sail and regatta boats or horses. What is more, clients often announce their requirements only days before the Games start, which adds further to the logistical complexity (Minis, Paraschi, et al., 2006).

\section{Defining Logistics Activities}

For sports logistics managers, it is critical to follow an already established logistics or supply chain model to manage the four pillars of athletes, venue, fans and equipment logistics. We argue that the SCOR model - which has been widely adopted by corporations (e.g. Zhou et al., 2011) - provides a useful foundation for sports logistics managers as it focusses on six core process within logistics, namely contains plan, source, make, deliver and return and enable (APICS, 2015). Originally constructed for manufacturing operations, the SCOR model has also been widely used in service operations (Giannakis, 2011) where is has been adapted to fit the respective service features.

For sports logistics management - and in the context of our SLF Framework - we argue that four of the six core processes have immediate relevance, whereas Make and Return need to be interpreted differently to best reflect the focus on sport events.

The first core process Plan involves the activities related to developing plans to align resources with demand, while the second core process Source involves the buying or acquiring of required materials and services. Make - originally described as the conversion of products within the supply chain (APICS, 2015) - can be defined in sports logistics as the process of 'assembling' materials and services to provide a value-added service to fans and athletes. Deliver involves the classical activities of logistics management including transportation, customs clearance and final delivery as well as installation. Return, originally 
described as activity associated with the reverse flow of goods (APICS, 2015), can be defined in the context of sports logistics as sustainable efforts to return temporarily used materials as well as the respective clean ups after the events. Enable involves the management of all above mentioned processes with regard to logistics information, relationships and performance.

Against this background, we define sports logistics management in the context of events as: "the planning, implementing, and controlling procedures for the efficient and effective forward and reverse flow of goods, capacity, services, and related information between the point of origin and event destination in order to meet the venue organisers and athletes requirements and enlighten, celebrate, entertain or challenge the experience of a group of people.”

\section{Research Design}

Building on the conceptual and conceptual advancements presented above, one research aim was to conduct a systematic literature review that synthesizes sport logistics research that has been published to date. Before presenting the results of this review, it seems important to highlight how review articles are able to make a significant scholarly contribution. In going beyond the "traditional literature review" that provides the scholarly background for studies published in journal articles, four encompassing methods of conducting "research of research" have been proposed: meta-analysis, systematic review, qualitative review, and integrative review (for further detail, see Schulenkorf et al., 2016). For the purpose of our study, we employed a systematic literature review as it provides high-quality evidence by adopting a replicable, rigorous, and transparent process for synthesizing scientific knowledge (Tranfield et al., 2003). Thus, a systematic review represents the ideal method to achieve this paper's research aim which is to provide a structured recognition of logistics ins sports and highlight opportunities for future research.

There are warnings, however, that the complexity inherent in large systematic review studies may come at the expense of academic quality and accuracy (O'Mathúna, 2000; Torraco, 2005). It is therefore critical to formulate a stringent research framework with clear strategies and processes to ensure academic rigor. As such, this paper applies the well-accepted six-step systematic literature review approach established by Durach et al. (2017) and outlined below. Moreover, to reduce any potential research bias, our study involves multiple researchers from different countries, searches two databases, and avoids limiting itself to specific publications. 


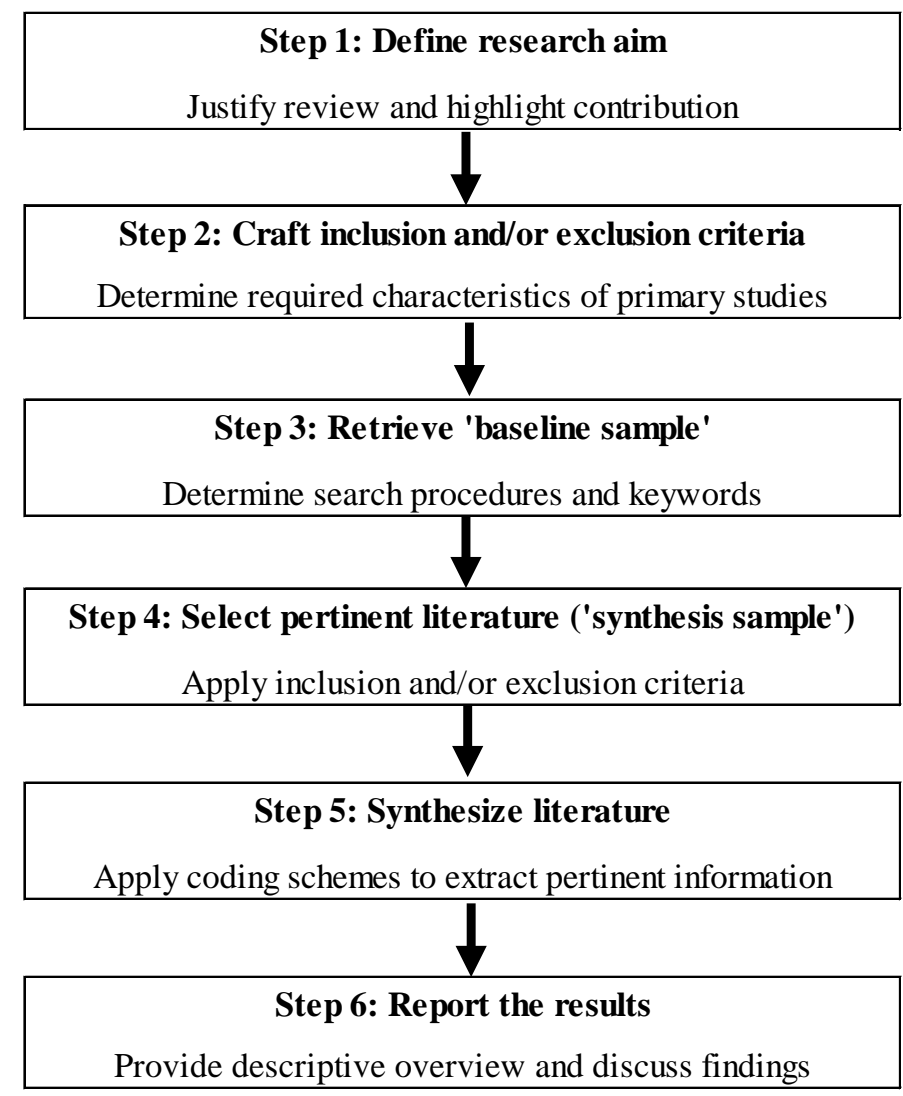

Figure 2: Steps for conducting a systematic literature review (adapted from Durach et al., 2017)

\section{Step 1: Define research aim}

As stated in the introduction, no research-driven characterization of 'sports logistics management' exists. Thus, our study uses the newly proposed SLF framework as the conceptual background to reach the aim of analyzing and synthesizing existing sports logistics management literature, and to highlight opportunities for future research. This approach is in line with Durach et al. (2017) recommendation of employing a framework that reveals the scope of the review study, the study context and the definition of the constructs used.

\section{Step 2: Craft inclusion and/or exclusion criteria}

To follow Durach et al.'s (2017) methodological approach, an inclusion criteria list was developed and agreed on by all authors (see Table 2). As systematic literature reviews in logistics can benefit from empirical (qualitative, quantitative and mixed methods) as well as modeling research, scholars encourage reviewers to include a wide range of studies (Durach et al., 2015; McKinnon, 2013; Pawson, 2006). As a consequence, it was decided to not restrict the search to particular journals or research methods. However, in our review we focused on peerreviewed articles only, as they are considered to be of higher academic standard than non-peerreviewed articles (Denyer and Tranfield, 2009; Light and Pillemer, 1984). Moreover, we only selected papers that were published between the years 2000 - the year which can be regarded 
as the starting point for the emergence of the globalization of sports (Maguire, 2000) - and mid2019, the time of data collection. It needs to be emphasized that our search deals with content related to logistics in the context of sports and sport events only; as such, relevant articles had to demonstrate a specific focus on sports and logistics management practices as identified in the SLF framework. Consequently, all peer-reviewed articles which did not fulfil this criterion were excluded from this study.

\section{Table 2: Inclusion criteria}

Inclusion criteria $\quad$ Rationale

\section{Peer-reviewed articles}

Selection of papers published 2000 to mid-2019

Summary must address a logistics aspect (as identified in the SLF framework) within the context of sport events and is, at least, one of the focus of the paper

Different type of article considered (e.g. empirical, conceptual)

Article must be written in English
Published peer-reviewed articles increase the quality of the manuscript (Denyer and Tranfield, 2009) and enhance the quality control (Light and Pillemer, 1984)

The year 2000 was selected as a starting point due to the emergence of studies on sports and globalization (Maguire, 2000)

The aim of the review is to analyze and synthesize the different features of sports logistics management to improve conceptual clarity and understanding

The focus of the study is to evaluate and synthesize the various topics approaches to the concept of sports logistics management

English is the dominant research language in the field of logistics, event and sports management

\section{Step 3: Retrieve 'baseline sample'}

As a third step, we aimed to retrieve a 'baseline sample' of potentially relevant literature. To reduce bias, two databases were selected for the literature search: Business Source complete (via EBSCO) and the SSCI-Database (via ISI Web of Knowledge). These databases were selected as they represent large repositories of business research, providing a broad range of publishing outlets of highest impact for the research community (Carter and Easton, 2011; Sandberg and Aarikka-Stenroos, 2014), Following Denyer and Tranfield (2009) and Durach et al. (2017), a team of four senior researchers - from different countries and specializing in logistics and sports management - validated the initial search terms based on the research aim and the inclusion criteria. After the initial search terms had been identified, the team developed incremental keywords and extended the search string by indicating synonyms for each logistics pillar in the SLF framework.

In particular, and in line with other systematic literature reviews, we searched for sports logistics management articles in the databases by applying the keyword "sport" in combination with "logistics", "infrastructure”, "supply chain” or "transport” (see Table 3). To expand our scope and include as many relevant articles as possible, we repeated the search and replaced "sport” with specific sports and events, including "football”, "soccer”, "golf”, "basketball”, 
“athlete”, “Olympic”, “World Cup”, "Formula 1" or exchanged "sport” with "venue” or "facility". However, keywords with similar meaning that are not related to the research aim, e.g. "logistic" (from logistic regression), were excluded from the search.

For each database, the search string had to be adjusted according to the specific search guidelines and was then applied in the search field offering the most relevant results. To further ensure that our selection captured all relevant academic articles that deal with sports logistics management, we also conducted subsequent citation searches. These searches were first carried out in February 2019 and repeated in June 2019.

Table 3: Keywords and search string

\begin{tabular}{|c|c|c|}
\hline Construct & Original search string & Databases \\
\hline $\begin{array}{l}\text { Sports Logistics } \\
\text { Management }\end{array}$ & $\begin{array}{l}\text { (AB (“sport”)) AND (AB ("logistics”) OR AB } \\
\text { ("SCM") OR AB (“infrastructure”) OR AB } \\
\text { ("supply chain") OR AB ("transport")) AND } \\
\text { NOT AB (“logistic”) }\end{array}$ & $\begin{array}{l}\text { Business Source } \\
\text { Complete } \\
\text { SSCI }\end{array}$ \\
\hline
\end{tabular}

Note: $A B=$ Abstract

\section{Step 4: Select pertinent literature}

In this fourth step, the inclusion criteria from step 2 was applied to 'synthesize the sample' (Durach et al., 2017), i.e. relevant articles were included while irrelevant articles were excluded. The original search process resulted in the identification of 221 articles from Business Source Complete and 182 articles from SSCI. The incongruence of results is due to the different listings of literature and literature types in the databases; however, the searches provided a significant overlap of the results, which indicates a substantial consistency of the search strings (Durach et al., 2015).

Two authors then eliminated duplicate articles and analyzed all available abstracts according to the inclusion criteria. All abstracts were read independently in a blind procedure by the two authors to enhance validity. To ensure inter-coder reliability and added transparency, a third researcher became involved in case of disagreement; however, only 4 per cent of the abstracts resulted in disagreement between the researchers. The calculated Cohen's $\kappa$ was 0.91 (Cohen, 1960), which indicates high reliability of the process of inclusion and exclusion of articles (Landis and Koch, 1977).

Overall, our selection process reduced the number of articles for analysis and synthesis to 46 . These articles were then shared and read in full by two authors, to confirm the actual relevance (Durach et al., 2017). In this final step, 19 articles were excluded for a lack of fit, while an additional six articles were identified through cross-referencing. This led to a final sample of 33 pertinent articles, of which 13 were published in A*/A-ranked journals, 10 in B-ranked journals and 10 in C/not-ranked journals according to the current ABDC Journal Quality List. More than half of the contributions were published in the last five years. The article selection process is shown in Figure 3 below. 


Database
search in
Business
Source
Complete and
SSCI

403
Eliminating duplicate articles and studying abstracts as per inclusion criteria

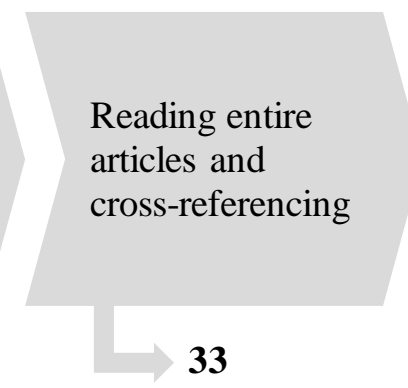

Figure 3: Article selection process

\section{Step 5: Synthesize literature}

The final sample of 33 articles was analyzed and synthesized with the aim to provide a comprehensive overview about studies that are related to various logistics activities in sports and sport event management. Further, the content of the articles was to be analyzed against the newly established SLF Framework and in particular, against the above-identified key pillars of sports logistics athletes, venue, fan \& spectator, and equipment logistics management. This was important to determine the predominant focus of publications and current research gaps.

As recommend by Rousseau et al. (2008), when synthesizing articles of heterogenous nature and where a large part of the sample comprises qualitative studies, an interpretative synthesis approach should be taken. In our case, this involved flexible and open coding schemes or topics by the authors. As such, within the 33 articles included and reviewed for our study, eight critical topics were identified under the four pillars (see Table 4). Each of these topics represents a unique feature or dimension within the key pillars of sports logistics management. Moreover, each one was identified according to its role in facilitating management planning, and in assessing, monitoring and sports logistics issues. As such, the allocation of the papers according to the key pillars and topics also provides a solid foundation for identifying gaps and proposing directions for future research.

Table 4: Topics by author

\begin{tabular}{|c|c|c|}
\hline Key Pillar & Topic & Authors \\
\hline \multirow[t]{3}{*}{$\begin{array}{l}\text { Venue Logistics } \\
\text { Management }\end{array}$} & Venue Operations & $\begin{array}{l}\text { Minis et al. (2006b), Wright (2009), Bamford et } \\
\text { al. (2015), Kauppi et al. (2013) }\end{array}$ \\
\hline & $\begin{array}{l}\text { Sustainability \& } \\
\text { Venue Legacy }\end{array}$ & $\begin{array}{l}\text { Preuss (2015), Sant \& Mason (2015), Preuss } \\
\text { (2007), Drummond \& Cronje (2018), Van den } \\
\text { Hurk \& Verhoest (2017), Smith \& Smith } \\
\text { (2008) }\end{array}$ \\
\hline & Security & $\begin{array}{l}\text { Whisenant (2003), Minis et al. (2006b), Hall, } \\
\text { Marciani, Cooper \& Phillips (2010) }\end{array}$ \\
\hline $\begin{array}{l}\text { Fan \& } \\
\text { Spectators }\end{array}$ & $\begin{array}{l}\text { Infrastructure \& } \\
\text { Legacy }\end{array}$ & $\begin{array}{l}\text { Malhado \& Araujo (2017), Pereira (2018), } \\
\text { Preuss (2015), Sant \& Mason (2015), Wilson } \\
\text { (2015), Kassens-Noor (2013), Bovy (2009) }\end{array}$ \\
\hline
\end{tabular}




\section{Logistics \\ Management}

\begin{tabular}{|c|c|c|}
\hline & $\begin{array}{l}\text { Transportation and } \\
\text { Sustainability }\end{array}$ & $\begin{array}{l}\text { Bovy (2006), Han, Wong \& Ho (2018), } \\
\text { Kassens-Noor (2010), Jiang (2008), Mulley \& } \\
\text { Moutou (2015), Mahoney \& McMillen (2014), } \\
\text { Minis et al. (20106b), Dolles and Soderman } \\
\text { (2010) } \\
\text { Ghoniem, Ali, Al-Salem \& Khallouli (2017), } \\
\text { Bamford et al. (2015), Kauppi et al. (2013), } \\
\text { Smith \& Smith (2008), Kassens-Noor et al. } \\
\text { (2018), Currie \& Shalaby (2012), Minis et al. } \\
\text { (2006b) }\end{array}$ \\
\hline $\begin{array}{l}\text { Equipment } \\
\text { Logistics } \\
\text { Management }\end{array}$ & Transportation & $\begin{array}{l}\text { Minis et al. (2006b), Bamford et a. l(2015), } \\
\text { Kauppi et al. (2013), Wright (2009), Browne, } \\
\text { Allen, Wainwright, Palmer \& Williams (2014) }\end{array}$ \\
\hline $\begin{array}{l}\text { Athletes } \\
\text { Logistics } \\
\text { Management }\end{array}$ & Travel & $\begin{array}{l}\text { Huyghe et al. (2018), Roy \& Forest (2018), } \\
\text { Bamford \& Dehe(2016), Kauppi et al. (2013), } \\
\text { Bovy (2009), Wright (2009), Minis at al. } \\
\text { (2006a), Minis et al. (2006b) }\end{array}$ \\
\hline
\end{tabular}

\section{Step 6: Report the results}

This final step presents the results from all selected studies, their relation to each other, and what is currently known and not known to the academic community (Denyer and Tranfield, 2009). Moreover, the analysis and synthesis of results will provide an informed interpretation of the scientific evidence relating to the research aim and the gaps found in the review process (Rousseau et al., 2008). As such, the following section outlines our results on the current state of sports logistics management. 
Table 5: Summary of the reviewed papers

\begin{tabular}{|c|c|c|c|c|c|c|c|}
\hline No. & $\begin{array}{l}\text { Author } \\
\text { (year) }\end{array}$ & Journal & Title & $\begin{array}{l}\text { Venue Logistics } \\
\text { Management }\end{array}$ & $\begin{array}{c}\text { Fan \& } \\
\text { Spectator } \\
\text { Logistics } \\
\text { Management }\end{array}$ & $\begin{array}{l}\text { Sports- } \\
\text { /Equipment } \\
\text { Logistics } \\
\text { Management }\end{array}$ & $\begin{array}{c}\text { Athletes } \\
\text { Logistics } \\
\text { Management }\end{array}$ \\
\hline 1 & $\begin{array}{l}\text { Drummond } \\
\text { \& Cronje } \\
\text { (2018) }\end{array}$ & $\begin{array}{l}\text { International } \\
\text { Journal of Sport } \\
\text { Policy and Politics }\end{array}$ & $\begin{array}{l}\text { Building a white elephant? The } \\
\text { case of the Cape Town Stadium }\end{array}$ & Ancillary & Core & Absent & Absent \\
\hline 2 & $\begin{array}{l}\text { Han et al. } \\
\text { (2018) }\end{array}$ & $\begin{array}{l}\text { Asia Pacific Journal } \\
\text { of Tourism Research }\end{array}$ & $\begin{array}{l}\text { Residents' perceptions on the } \\
\text { traffic impact of a special event: } \\
\text { a case of the Macau Grand Prix }\end{array}$ & Absent & Core & Absent & Absent \\
\hline 3 & $\begin{array}{l}\text { Huyghe et } \\
\text { al. (2018) }\end{array}$ & Sports & $\begin{array}{l}\text { The Negative Influence of Air } \\
\text { Travel on Health and } \\
\text { Performance in the National } \\
\text { Basketball Association: A } \\
\text { Narrative Review }\end{array}$ & Absent & Absent & Absent & Core \\
\hline 4 & $\begin{array}{l}\text { Kassens- } \\
\text { Noor et al. } \\
\text { (2018) }\end{array}$ & $\begin{array}{l}\text { Journal of Planning } \\
\text { Education and } \\
\text { Research }\end{array}$ & $\begin{array}{l}\text { Olympic Transport Legacies: } \\
\text { Rio de Janeiro’s Bus Rapid } \\
\text { Transit System }\end{array}$ & Absent & Core & Absent & Absent \\
\hline 5 & $\begin{array}{l}\text { Pereira } \\
(2018)\end{array}$ & Cities & $\begin{array}{l}\text { Transport legacy of mega- } \\
\text { events and the redistribution of } \\
\text { accessibility to urban } \\
\text { destinations }\end{array}$ & Absent & Core & Absent & Absent \\
\hline 6 & $\begin{array}{l}\text { Roy \& } \\
\text { Forest } \\
\text { (2018) }\end{array}$ & $\begin{array}{l}\text { Journal of Sleep } \\
\text { Research }\end{array}$ & $\begin{array}{l}\text { Greater circadian disadvantage } \\
\text { during evening games for the } \\
\text { National Basketball Association } \\
\text { (NBA), National Hockey } \\
\text { League (NHL) and National } \\
\text { Football League (NFL) teams } \\
\text { travelling westward }\end{array}$ & Absent & Absent & Absent & Core \\
\hline 7 & $\begin{array}{l}\text { Ghoniem et } \\
\text { al. (2017) }\end{array}$ & $\begin{array}{l}\text { Journal of the } \\
\text { Operational } \\
\text { Research Society }\end{array}$ & $\begin{array}{l}\text { Prescriptive analytics for FIFA } \\
\text { World Cup lodging capacity } \\
\text { planning }\end{array}$ & Absent & Core & Absent & Absent \\
\hline 8 & $\begin{array}{l}\text { Malhado \& } \\
\text { Araujo } \\
\text { (2017) }\end{array}$ & Event Management & $\begin{array}{l}\text { Welcome to Hell: Rio } 2016 \\
\text { Olympics Failing to Secure } \\
\text { Sustainable Transport Legacy }\end{array}$ & Absent & Core & Absent & Absent \\
\hline
\end{tabular}




\begin{tabular}{|c|c|c|c|c|c|c|c|}
\hline 9 & $\begin{array}{l}\text { Van den } \\
\text { Hurk \& } \\
\text { Verhoest } \\
(2017)\end{array}$ & $\begin{array}{l}\text { Sport Management } \\
\text { Review }\end{array}$ & $\begin{array}{l}\text { On the fast track? Using } \\
\text { standard contracts in public- } \\
\text { private partnerships for sports } \\
\text { facilities: A case study }\end{array}$ & Core & Absent & Absent & Absent \\
\hline 10 & $\begin{array}{l}\text { Bamford\& } \\
\text { Dehe } \\
\text { (2016) }\end{array}$ & $\begin{array}{l}\text { International } \\
\text { Journal of Quality \& } \\
\text { Reliability } \\
\text { Management }\end{array}$ & $\begin{array}{l}\text { Service quality at the London } \\
2012 \text { games-a paralympics } \\
\text { athletes survey }\end{array}$ & Absent & Absent & Absent & Core \\
\hline 11 & $\begin{array}{l}\text { Bamford et } \\
\text { al. (2015) }\end{array}$ & $\begin{array}{l}\text { Public Sector } \\
\text { Operations } \\
\text { Management }\end{array}$ & $\begin{array}{l}\text { Going the distance: Sport } \\
\text { operations management in the } \\
\text { public and third sectors }\end{array}$ & Ancillary & Core & Ancillary & Ancillary \\
\hline 12 & $\begin{array}{l}\text { Mulley \& } \\
\text { Moutou } \\
\text { (2015) }\end{array}$ & Cities & $\begin{array}{l}\text { Not too late to learn from the } \\
\text { Sydney Olympics experience: } \\
\text { Opportunities offered by } \\
\text { multimodality in current } \\
\text { transport policy }\end{array}$ & Absent & Core & Absent & Absent \\
\hline 13 & $\begin{array}{l}\text { Preuss } \\
(2015)\end{array}$ & Leisure Studies & $\begin{array}{l}\text { A framework for identifying the } \\
\text { legacies of a mega sport event }\end{array}$ & Ancillary & Core & Absent & Absent \\
\hline 14 & $\begin{array}{l}\text { Sant \& } \\
\text { Mason } \\
(2015)\end{array}$ & $\begin{array}{l}\text { Journal of Sport } \\
\text { Management }\end{array}$ & $\begin{array}{l}\text { Framing event legacy in a } \\
\text { prospective host city: Managing } \\
\text { Vancouver’s Olympic bid }\end{array}$ & Ancillary & Core & Absent & Absent \\
\hline 15 & $\begin{array}{l}\text { Wilson } \\
(2015)\end{array}$ & $\begin{array}{l}\text { International } \\
\text { Journal of the } \\
\text { History of Sports }\end{array}$ & $\begin{array}{l}\text { Sports infrastructure, legacy and } \\
\text { the paradox of the } 1984 \\
\text { Olympic Games }\end{array}$ & Ancillary & Core & Absent & Absent \\
\hline 16 & $\begin{array}{l}\text { Browne et } \\
\text { al. (2014) }\end{array}$ & $\begin{array}{l}\text { International } \\
\text { Journal of Urban } \\
\text { Sciences }\end{array}$ & $\begin{array}{l}\text { London 2012: changing } \\
\text { delivery patterns in response to } \\
\text { the impact of the Games on } \\
\text { traffic flows }\end{array}$ & Absent & Absent & Core & Absent \\
\hline 17 & $\begin{array}{l}\text { Mahoney \& } \\
\text { McMillen } \\
\text { (2014) }\end{array}$ & $\begin{array}{l}\text { Journal of Facility } \\
\text { Planning, Design, } \\
\text { and Management }\end{array}$ & $\begin{array}{l}\text { Facility planning, design, and } \\
\text { management of mobility } \\
\text { assistance programs: Review } \\
\text { and recommendations of } \\
\text { accessible routes from super } \\
\text { bowl XLV }\end{array}$ & Ancillary & Core & Absent & Absent \\
\hline 18 & $\begin{array}{l}\text { Kassens- } \\
\text { Noor } \\
\text { (2013) }\end{array}$ & $\begin{array}{l}\text { Journal of Urban } \\
\text { Affairs. }\end{array}$ & $\begin{array}{l}\text { Transport legacy of the Olympic } \\
\text { Games, 1992-2012 }\end{array}$ & Ancillary & Core & Absent & Absent \\
\hline
\end{tabular}




\begin{tabular}{|c|c|c|c|c|c|c|c|}
\hline 19 & $\begin{array}{l}\text { Kauppi et } \\
\text { al. (2013) }\end{array}$ & $\begin{array}{l}\text { International } \\
\text { Journal of } \\
\text { Operations \& } \\
\text { Production } \\
\text { Management }\end{array}$ & $\begin{array}{l}\text { Should we try out for the major } \\
\text { leagues? A call for research in } \\
\text { sport operations management }\end{array}$ & Ancillary & Ancillary & Core & Ancillary \\
\hline 20 & $\begin{array}{l}\text { Currie \& } \\
\text { Shalaby } \\
\text { (2012) }\end{array}$ & Transport Reviews & $\begin{array}{l}\text { Synthesis of transport planning } \\
\text { approaches for the world's } \\
\text { largest events }\end{array}$ & Absent & Core & Absent & Absent \\
\hline 21 & $\begin{array}{l}\text { Dolles \& } \\
\text { Soederman }\end{array}$ & $\begin{array}{l}\text { Journal of } \\
\text { Management \& } \\
\text { Organization }\end{array}$ & $\begin{array}{l}\text { Addressing ecology and } \\
\text { sustainability in mega-sporting } \\
\text { events: The } 2006 \text { football World } \\
\text { Cup in Germany }\end{array}$ & Core & Core & Absent & Absent \\
\hline 22 & $\begin{array}{l}\text { Hall et al. } \\
\text { (2010) }\end{array}$ & $\begin{array}{l}\text { Journal of Venue } \\
\text { and Event } \\
\text { Management }\end{array}$ & $\begin{array}{l}\text { Needs, concerns, and future } \\
\text { challenges in security } \\
\text { management of NCAA Division } \\
\text { I football events: An } \\
\text { intercollegiate facility } \\
\text { management perspective }\end{array}$ & Core & Absent & Absent & Absent \\
\hline 23 & $\begin{array}{l}\text { Kassens- } \\
\text { Noor } \\
(2010)\end{array}$ & $\begin{array}{l}\text { Transportation } \\
\text { Research Record: } \\
\text { Journal of the } \\
\text { Transportation } \\
\text { Research Board }\end{array}$ & $\begin{array}{l}\text { Sustaining the momentum: } \\
\text { Olympics as potential catalyst } \\
\text { for enhancing urban transport }\end{array}$ & Absent & Core & Absent & Absent \\
\hline 24 & $\begin{array}{l}\text { Bovy } \\
(2009)\end{array}$ & $\begin{array}{l}\text { Public Transport } \\
\text { International }\end{array}$ & $\begin{array}{l}\text { Beijing } 2008 \text { Olympic Games } \\
\text { success: Massive public } \\
\text { transport developments and } \\
\text { major road traffic reduction }\end{array}$ & Absent & Core & Absent & Absent \\
\hline 25 & $\begin{array}{l}\text { Wright } \\
\text { (2009) }\end{array}$ & $\begin{array}{l}\text { Journal of the } \\
\text { Operational } \\
\text { Research Society }\end{array}$ & 50 years of OR in sport & Ancillary & Ancillary & Ancillary & Ancillary \\
\hline 26 & $\begin{array}{l}\text { Jiang } \\
(2008)\end{array}$ & $\begin{array}{l}\text { Journal of } \\
\text { Transportation } \\
\text { Systems Engineering } \\
\text { and Information } \\
\text { Technology }\end{array}$ & $\begin{array}{l}\text { Analysis on Beijing Subway } \\
\text { flows during the 29th Olympics }\end{array}$ & Absent & Core & Absent & Absent \\
\hline 27 & $\begin{array}{l}\text { Minis \& } \\
\text { Tsamboulas } \\
\text { (2008) }\end{array}$ & Transport Reviews & $\begin{array}{l}\text { Contingency planning and war } \\
\text { gaming for the transport } \\
\text { operations of the Athens } 2004 \\
\text { Olympic Games }\end{array}$ & Absent & Absent & Core & Absent \\
\hline
\end{tabular}




\begin{tabular}{|c|c|c|c|c|c|c|c|}
\hline 28 & $\begin{array}{l}\text { Smith \& } \\
\text { Smith } \\
\text { (2008) }\end{array}$ & $\begin{array}{l}\text { Services Marketing } \\
\text { Quarterly }\end{array}$ & $\begin{array}{l}\text { Exploring the service location } \\
\text { strategies behind super bowl } \\
\text { venue selection }\end{array}$ & Core & Ancillary & Absent & Absent \\
\hline 29 & $\begin{array}{l}\text { Preuss } \\
(2007)\end{array}$ & $\begin{array}{l}\text { Journal of Sport \& } \\
\text { Tourism }\end{array}$ & $\begin{array}{l}\text { The conceptualisation and } \\
\text { measurement of mega sport } \\
\text { event legacies }\end{array}$ & Core & Ancillary & Absent & Absent \\
\hline 30 & $\begin{array}{l}\text { Bovy } \\
(2006)\end{array}$ & $\begin{array}{l}\text { Public Transport } \\
\text { International }\end{array}$ & $\begin{array}{l}\text { Solving outstanding mega-event } \\
\text { transport challenges: the } \\
\text { Olympic experience }\end{array}$ & Ancillary & Core & Absent & Absent \\
\hline 31 & $\begin{array}{l}\text { Minis et al. } \\
\text { (2006a) }\end{array}$ & $\begin{array}{l}\text { Transportation } \\
\text { Research Part A: } \\
\text { Policy and Practice }\end{array}$ & $\begin{array}{l}\text { Contribution to the design of the } \\
\text { Athletes Bus Network during } \\
\text { the Athens } 2004 \text { Olympic } \\
\text { Games }\end{array}$ & Absent & Absent & Absent & Core \\
\hline 32 & $\begin{array}{l}\text { Minis et al. } \\
\text { (2006b) }\end{array}$ & $\begin{array}{l}\text { International } \\
\text { Journal of Physical } \\
\text { Distribution \& } \\
\text { Logistics } \\
\text { Management }\end{array}$ & $\begin{array}{l}\text { The design of logistics } \\
\text { operations for the Olympic } \\
\text { Games }\end{array}$ & Ancillary & Ancillary & Core & Ancillary \\
\hline 33 & $\begin{array}{l}\text { Whisenant } \\
\text { (2003) }\end{array}$ & Facilities & $\begin{array}{l}\text { Using biometrics for sport } \\
\text { venue management in a post 9- } \\
11 \text { era }\end{array}$ & Core & Absent & Absent & Absent \\
\hline
\end{tabular}




\section{Results and Discussion}

In presenting our study results, we first provide a snapshot of the 33 papers from our review based on their categorization into the four identified pillars of sports logistics management: venue logistics management, fan \& spectator logistics management, equipment management, and athletes management (see Table 5). We then continue by discussing the most significant results under each of the pillars and sub-topics.

The summary table above lists all relevant articles and their specific logistics management foci, classified and categorized into 'Absent', 'Ancillary' and 'Core' in terms of level of engagement. As such, the table provides the current status of sport logistics management and highlight that the majority of studies labelled 'Core' have focused on fan \& spectator logistics (19), followed by venue logistics management (6) and athletes and equipment management (4 each). We will now discuss our results under each pillar and topic in more detail.

\section{Venue logistics management}

Our review reveals that venue logistics management research for sports events is mainly driven by sustainability and legacy studies, while papers dealing with security or even classical tasks such as transportation and venue operations management are underrepresented. Most of the authors acknowledge the importance of venue logistics management as a precondition for providing a good experience to the audience, but fail to discuss the logistics requirements in detail (e.g. Minis, Paraschi, et al., 2006).

\section{Sustainability and venue legacy}

A strong focus is placed on sustainability issues and venue legacy in venue logistics management. This suggests that venue logistics managers and policymakers need be aware of the implications of the venue infrastructure on the environment before, during and after sports events. For example, Drummond and Cronje (2018) argue that the stadium built for the FIFA World Cup in 2010 in Cape Town was a logistical risk and can be regarded as problematic due to the minimal post-event usage, concluding sports event expectations and post-event realities are often a mismatch. In contrast, Wilson (2015) investigated the legacy of the 1984 Olympics and found that the newly build venues for the Games laid the groundwork for the construction or improvement of nearly 100 sport facilities in three decades after the Games. Preuss (2007) and Preuss (2015) discusses the role of stakeholder in the legacy process of mega and large sports events and presents frameworks and concepts to evaluate venue legacies. On a smaller scale, Van den Hurk and Verhoest (2017) investigated the Belgian sport sector and how contract management and public-private-partnerships (PPP) influence the build sports hall or multifunctional sports centers. Finally, by investigating venue logistics management from a location strategy perspective, Smith and Smith (2008) analyze Super Bowl locations and what standards and criteria are used by the National Football League (NFL) to be chosen as a host. Here, specific venue-site factors that involve the capacity of the arena for spectators, media and the team facilities highlight the importance of venue logistics management.

\section{Venue operations}


From an operational perspective, venue logistics include the planning, implementation and management of logistics activities such as scheduling, warehousing, shipping, distribution, supply and asset management (Minis, Paraschi, et al., 2006). Most authors see venue operations are a potential and growing research area. For example, Kauppi et al. (2013) call for more operations management research and see the large numbers of venues as a starting point. As venues require significant coordination, this provides a rich testing ground from a managerial perspective, while larger events offer research opportunities due to the high demand for diverse services in venues over a very short period of time. Meanwhile, Bamford et al. (2015) examine the application of operations management strategies to off-field sporting operations in the context of public and third sector sporting organisations. Their study focuses on planning, scheduling and controlling sports operations and highlights emerging themes. Finally, Minis, Paraschi, et al. (2006) argue that venue operations at mega events such as the Olympic Games require a systematic process for planning and designing including predictive operational forecasting to anticipate and calculate demand. Here, the authors go beyond questions around standard operation processes and enter the field of forecasting, which in itself provides significant opportunities for quantitative modelling for logistical improvements or streamlining.

\section{Security}

Although it can be regarded as a narrow topic in venue logistics management, we found three papers that discuss security issues. S. Hall et al. (2010) used the National Collegiate Athletic Association (NCAA) Division I football event to provide a comprehensive study about security management to determine the needs, concerns, and future challenges. The authors argue that security management at venues is not only problematic due to crowd management issues and the choice of sports events as potential terrorist targets, but also because key personnel seems to lack training in case of an emergency. While S. Hall et al. (2010) focus on social and contextual factors that may cause security concerns, Whisenant (2003) focus on potential solutions. In particular, he assessed biometric technologies which may be used to prevent any act of anti-social behavior including violence in sports venues. Finally - and rather unrelated to the previous two examples - is Minis, Paraschi, et al. (2006) study on security issues in the context of the 2004 Olympic Games. Here, the authors describe and discuss the operations of managing a dedicated vehicle security and flow screening area.

\section{Fan and spectator logistics management}

While venue logistics management comprises all logistics activities that happen inside the venue, the pillar fan and spectator logistics management is mostly concerned with logistics activities outside the venue. Most of studies discuss and analyze different facets regarding the transportation of fans and spectators to the venue, including the planning and implementation stages. Similar to the venue logistics management pillar, infrastructure decisions and their impact on legacy are areas with a strong research focus.

\section{Infrastructure and legacy}

Investments and legacy planning are the most dominant topics for sports logistics researchers, with seven papers addressing these factors, largely from a mega event perspective. For example, Bovy (2009) analyses the investments in infrastructure at the Beijing Olympic Games and highlights the implications of the metro system expansion from a 3-line system to 
a 7-line system. With a similar focus, Malhado and Araujo (2017) examine the urban transport system of the Rio 2016 Olympic Games. Meanwhile, Kassens-Noor (2013) takes a broader focus and investigates transport legacies of the Olympic Games. She finds that infrastructural legacies are not always place-specific, but are much more uniform across the host cities. With a focus on potential new infrastructure for fans and spectators, Sant and Mason (2015) investigate the legacy characteristics of the Vancouver Olympic Games bid and suggested that spectators value intangible benefits over investments in infrastructure. Finally, Preuss (2015) developed a framework to identify the legacies of mega sport events, including a specific focus on how to judge whether a legacy creates or destroys value.

\section{Transportation and Sustainability}

Six papers focus specially on the logistics aspect of the fan and spectator transportation issues for sports events. For example, Jiang (2008) analyses the subway passenger flow during the Olympic Games in Beijing in 2008 and found that the design of specific train schedules and the extension of operating times of subway lines helped significantly to balance subway passenger volumes. In the same vein, Kassens-Noor (2010) and Bovy (2006) investigated transport challenges during the Olympic Games or how the Games impact urban transport systems. Here, the focus is placed on maximizing efficiencies from a practical and policy perspective. Meanwhile, Mulley and Moutou (2015) studied the transport arrangements at the Sydney Olympics and investigated the link between spectator travel times between the venues and tourism attractions. Here, the focus was on understanding multimodal trips by the travelling public. From a sustainability perspective, Dolles and Söderman (2010) investigated the transportation systems during the 2006 Soccer World Cup and highlighted the role of railways. Finally, Mahoney and McMillen (2014) used a mixed-method approach to analyse the requirements for disability routes to Super Bowl locations. With their focus on transportation options for disabled fans and spectators, they provided the only study that engaged with logistical aspects of social inclusion.

\section{Planning}

From a logistics planning perspective, the focus of sports logistics research is mainly related to major or mega events, neglecting local and regional events. Currie and Shalaby (2012) studied transport planning approaches for the Summer Olympic Games to outline the nature of transport demand and supply. More specifically, Minis, Paraschi, et al. (2006) highlight the importance of planning for the 2004 Olympic Games; and discuss, among other issues, the estimation of resources for the event. Meanwhile, Smith and Smith (2008) investigated the planning characteristics to host the Super Bowl. The authors confirm that logistics management for fans and spectators is a crucial aspect, as only a stadium with 70.000 seats or more, 600.000 square feet of exhibit space as well as enough quality hotel rooms within a one-hour drive for 35peer cent of the stadium's capacity are considered as a host for the Super Bowl. Finally, Bamford et al. (2015) and Kauppi et al. (2013) see transport planning as an opportunity for sports logistics research to further develop operations management and research techniques and tools.

\section{Athletes logistics management}

Most of the studies that we classified under the athletes logistics management topic discuss the perspective of athletes rather marginally. Of the eight papers, only Minis, Keys, et al. 
(2006) go into some specific detail when describing the requirements of the bus network for athlete transportation during the Athens 2004 Olympic Games. The authors identified several service specifications including the bus fleet size and organization of the network as well as the scheduling, service reliability and monitoring and control systems. On the same topic of athlete transportation, Bovy (2009) describe that 2000 buses were used for athlete transportation at the Beijing Games and $300 \mathrm{~km}$ of Olympic lanes were reserved during the mega event. However, the study does not include any more specific management implication regarding athletes in comparison to other stakeholders, such as fans or organisers. In contrast, Bamford and Dehe (2016) used the London 2012 Paralympic Game to investigate the specific service requirements of disabled athletes during the sports events. With a different focus in their works, Roy and Forest (2018) and Huyghe et al. (2018) combined athlete management with the analysis of sleeping patterns. While not specifically investigating the logistics aspect of athlete air travel, this aspect was listed as one part of the factors that may lead to reduction of winning percentages in the analysis of athletes across three major leagues, i.e. National Basketball Association, National Hockey League, and the National Football League.

\section{Equipment logistics management}

Interestingly, the classical functions of logistics, namely the transport including pick and delivery, route planning, customs clearance and so on seems to be heavily under-researched in a sporting context. We could only identify one paper to fit this category - the contribution by Minis and Tsamboulas (2008) on a methodological process for developing transport-related contingency plans to address pre-identified emergencies in the Olympic Games. Even Minis, Paraschi, et al. (2006), who describe the logistics design of the Olympic Games in 2000 and 2004, highlight the importance of equipment transportation and its functions, but do not provide a specific process or a framework that extensively discusses the equipment transportation process per se. Interestingly, several authors including Bamford et al. (2015), Kauppi et al. (2013) and Wright (2009) see classical transport management - and the specific equipment aspects of this field - as an opportunity for further research in the area of sports management.

\section{Identified gaps and directions for future research}

In this study, we examine the academic literature related to sports logistics management in the context of sports events not only to create a framework that characterizes the field and inspires scholarly discussions, but also to provide explicit insights and concrete recommendations for an emerging research agenda. Overall, our literature review highlights that several topics related to sport logistics management are severely underrepresented or indeed missing completely. Hence, we like to provide the following signposts.

Little attention has been given to classic sport event logistics processes and specific conceptual advancements in this area of research

Although a number of papers have addressed the subject of usual logistics processes for sports events (such as transportation, customs-clearance, warehousing and distribution etc.), the extant research has yet to consider the specific logistics processes and requirements that are needed to contribute directly to the success of a sports event. The lack of research in this space may be partly explained by the lack of a specific definition sports logistics management, as well as the 
absence of suitable theoretical or conceptual frameworks. Interestingly, only one of the identified papers carries the word 'logistic/s' in its title and a mere three articles focus on conceptualization or systematic review of literature (see Table 5), largely leaving the field to an array of single empirical inquires. We believe that the definition provided earlier and the SLF Framework presented in this paper provide the foundation for the suggested directions of future research.

In particular, the SLF Framework establishes a backbone for an applied analysis of logistics processes against the four key pillars to identify managerial success factors, acknowledging idiosyncrasies of the sport sector. Such analyses will also assist in validating or advancing the SLF Framework as a suitable managerial tool in the sport event logistics space. In addition, it may encourage scholars to contribute additional models and frameworks around sport logistics processes that can either be developed from scratch or be based on the various conceptual contributions from the sports and logistics literature that already exist to date.

Understanding of sports logistics management processes for local and regional sports events is poor

Out of the 33 papers identified in our review, 30 papers deal either with general sports logistics issues or are related to major or mega events. Only one paper (Van den Hurk \& Verhoest, 2017) examines the infrastructure requirements for local sports events and competitions. This is somewhat surprising, given that local events and community sports offer rich opportunities for relatively confined research in sports logistics such as coordination, scheduling, transport and mobility. Clearly, there are many more grassroots and amateur sport events happening every day and all around the globe than there are commercialized and media-attracting sport events in a year. In short, logistical aspects related to local and regional sport have been largely overlooked and in addressing this issue, future research could for example explore transportation issues in local or community sports groups and teams or examine local event schedules or even equipment requirements for community sports programs and events.

\section{No sight of ways in which athlete management can be optimized within and outside of venues}

We suggest that the logistics aspect of athlete management, in particular the mobility and transport area, has been heavily neglected. So far, no specific study has been conducted on the scheduling and travel aspects related to professional sports. However, such an investigation seems significant to improve the design and management of athletes en route, and to secure efficiencies for athletes and their entourage. For example, athletes in the three major leagues in the US, the National Basketball Association, National Hockey League and the National Football League have a very tight playing schedule and by inference, a very tight flights schedule. They are frequently moved across several time zones with significant impacts on their physical, social and emotional wellbeing - but also negative effects on the environment. However, not one paper has thus far discussed scheduling, transportation or any other logistics activities related to the transportation or travel of professional athletes. Moreover, athlete management with regard to transport between venues at the Olympic Games or the World Soccer Cup are only addressed by one single paper. On a wider scale, athlete management studies concerning accommodation requirements (e.g. hotels or Olympic village) seem to be ignored, too. Future research could therefore explore logistics requirements for and sustainability challenges of athletes' transportation or design logistics models to examine professional athletes travel schedules in more detail.

Logistics elements of venue management have been partially explored 
Our review suggests that the infrastructure and legacy aspects of venue management have been relatively well researched. Interestingly, numerous studies on mega event legacies conclude that from an investment perspective, the often promoted and expected long-range effects do not match with sports event reality post-event (Alana Thomson, Schlenker, \& Schulenkorf, 2013). Apart from infrastructure and legacy research, only few studies address the operational aspects of venue management, including transportation and traffic flows within venues. In fact, studies that deal with specific logistics processes within venue highlight mainly the importance of venue logistics management, but seem to neglect logistics processes for specific venue functions such as coordination and planning off traffic flows to the special logistics demands for VIPs. Data-driven analytics may provide an avenue into this area, too. Hence, the challenge for future research in the area of venue logistics management is to find and develop realistic logistics cases and approaches within the venues to identify the logistics demands.

Research of sports logistics management lacks presence in leading academic sports and logistics journals

While our literature revealed that sports logistics management is represented in leading academic journals, only few studies are published in leading sports or logistics journals. In fact, a mere six articles are published in sports management journals, namely in Sport Management Review and Journal of Sport Management, and four in logistics journals, namely in International Journal of Physical Distribution \& Logistics Management, Transportation Research Part A: Policy and Practice, International Journal of Operations \& Production Management and the Journal of the Operational Research Society. As the majority of the studies to date have used other management domains to investigate sports logistics management activities - and as most of them have used sports logistics only as a context - future research can and should be grounded more specifically in logistics and sports management frameworks, models or approaches. Such developments are likely to facilitate the consideration of sport logistics management studies in leading sports and logistics management journals.

\section{Summary and Conclusion}

This paper contributes to the sports logistics management research space in three specific ways. First, the newly proposed Sport Logistics Framework (SLF) allows for a more structured recognition of logistics in sports in general and sport event management in particular. Second, the systematic literature review of sports logistics management establishes the status quo of current research in what is still considered an embryonic research area. As such, the structured recognition of logistics in sports holds both scholarly and managerial implications, yet the focus of this contribution was on providing the academic boundaries of this new playing field. Against this background, we finally provide evidence that there is more to be explored and offer respective guidance for future research. Especially, by categorizing sport logistics research into central pillars, we have been able to identify specific gaps and propose future research directions that we hope will lead to further conversation and collaboration between logistics and sport management researchers.

The identification of the scope and characteristics shows that sports logistics management is defined by three core elements (Figure 1 above). First, the scope of sports logistics management is defined by the types of sports events (i.e. local/regional, major, or mega sports events) which in turn are influenced by six specific characteristics, namely infrastructure, location, staff mix, audience, size and time/duration. Second, sports logistics management is embedded around four distinctive pillars which comprises athletes, venue, fan \& spectator and 
sports equipment logistics management. Third, the management of sports logistics should be underpinned by a reliable model that not only provides a structure, but that has been tested and adopted in practice. Here, the SCOR model provides a suitable managerial tool as it covers the different sports logistics activities of planning, sourcing, making, delivering, returning and enabling. For our specific sport-related purposes, we adapted the SCOR model to highlight the different stages for each sports logistics management key pillar. Based on these results, we also provided a first definition for the term 'sports logistics management'.

Concrete opportunities for further research lie in each of the four key pillars. With regard to equipment logistics management, researchers have so far given little attention to the classical logistics processes in sports and sports event management as we could not identify any logistics-specific frameworks or models. From an athletes logistics management perspective, transport and travel to and between venues, in particular in the context of mega-events or professional seasonal sports, provides an opportunity for future research. Moreover, from a venue logistics management perspective, the logistics processes including traffic flow within a venue have thus far been overlooked. And finally, most of the articles focus on major or mega-events, neglecting local or community sports events and the associated logistics activities.

Even so sport is a globally significant and growing industry, logistics management literature with its operational and strategic horizons has yet to resonate into the minds of sport (event) managers, policy makers and sport management scholars. We hope that both the gaps and challenges presented in this contribution will spark ideas, discussions and projects on how to fill this largely open canvas.

\section{References}

Aicher, T.J., Paule-Koba, A.L. and Newland, B. (2019), Sport facility and event management, Jones \& Bartlett Publishers,

Allen, J., O'Toole, W., Harris, R. and McDonnell, I. (2011), Festival \& special event management, Wiley \& Sons,

APICS, S.C.C. (2015), "SCOR Quick Reference Guide". Retrieved from https://www.apics.org/docs/default-source/scc-nonresearch/apicsscc_scor_quick_reference_guide.pdf

Bamford, D. and Dehe, B. (2016), "Service quality at the London 2012 games-a paralympics athletes survey", International Journal of Quality \& Reliability Management, Vol. 33 No. 2, pp. 142-159.

Bamford, D., Moxham, C., Kauppi, K. and Dehe, B. (2015), "Going the distance: Sport operations management in the public and third sectors", Public Sector Operations Management, Routledge, Vol. No., pp. 13-29.

Beis, D., Loucopoulos, P., Pyrgiotis, Y. and Zografos, K.G. (2006), "PLATO helps Athens win gold: Olympic Games knowledge modeling for organizational change and resource management", Interfaces, Vol. 36 No. 1, pp. 26-42.

Bovy, P. (2003). "Mega sports event transportation and main mobility management issues". Paper presented at the Transport and Exceptional Public Events. Report of the One Hundred and Twenty Second Round Table on Transport EconomicsEuropean Conference of Ministers of Transport.

Bovy, P. (2006), "Solving outstanding mega-event transport challenges: the Olympic experience", Public Transport International, Vol. 6 No. 6, pp. 32-34. 
Bovy, P. (2009), "Beijing 2008 Olympic Games success: Massive public transport developments and major road traffic reduction", Public Transport International, Vol. 58 No. 3.

Bowdin, G., Allen, J., Harris, R., McDonnell, I. and O'Toole, W. (2012), Events management, Routledge

Bull, C. and Lovell, J. (2007), "The impact of hosting major sporting events on local residents: An analysis of the views and perceptions of Canterbury residents in relation to the Tour de France 2007", Journal of Sport \& Tourism, Vol. 12 No. 3-4, pp. 229248.

Carter, C.R. and Easton, P.L. (2011), "Sustainable supply chain management: evolution and future directions", International Journal of Physical Distribution \& Logistics Management, Vol. 41 No. 1, pp. 46-62.

Christopher, M. and Peck, H. (1997), "Managing logistics in fashion markets", The International Journal of Logistics Management, Vol. 8 No. 2, pp. 63-74.

Cohen, J. (1960), "A coefficient of agreement for nominal scales", Educational and psychological measurement, Vol. 20 No. 1, pp. 37-46.

Collignon, H. and Sultan, N. (2014), "Winning in the Business of Sports". Retrieved from https://www.atkearney.in/documents/10192/5258876/Winning+in+the+Business+of+ Sports.pdf/ed85b644-7633-469d-8f7a-99e4a50aadc8

Currie, G. and Shalaby, A. (2012), "Synthesis of transport planning approaches for the world's largest events", Transport Reviews, Vol. 32 No. 1, pp. 113-136.

Denyer, D. and Tranfield, D. (2009), "Producing a systematic review", in Buchanan, D. and Bryman, A. (Eds.), The Sage handbook of organizational research methods, Sage Publications Ltd, London, pp. 671-689.

Dolles, H. and Söderman, S. (2010), "Addressing ecology and sustainability in mega-sporting events: The 2006 football World Cup in Germany", Journal of Management \& Organization, Vol. 16 No. 4, pp. 587-600.

Drummond, R. and Cronje, J. (2018), "Building a white elephant? The case of the Cape Town Stadium", International Journal of Sport Policy and Politics, Vol. No., pp. 1-22.

Dubois, A., Hulthén, K. and Sundquist, V. (2019), "Organising logistics and transport activities in construction", The International Journal of Logistics Management.

Durach, C.F., Kembro, J. and Wieland, A. (2017), "A new paradigm for systematic literature reviews in supply chain management", Journal of Supply Chain Management, Vol. 53 No. 4, pp. 67-85.

Durach, C.F., Wieland, A. and Machuca, J.A. (2015), "Antecedents and dimensions of supply chain robustness: a systematic literature review", International Journal of Physical Distribution \& Logistics Management, Vol. 45 No. 1/2, pp. 118-137.

Emery, P. (2010), "Past, present, future major sport event management practice: The practitioner perspective", Sport Management Review, Vol. 13 No. 2, pp. 158-170.

Frawley, S. and Adair, D. (2014), Managing the football world cup, Plagrave Macmillan., London.

Frawley, S., Cobourn, S. and Adriaanse, J.A. (2016), "Governance, CSR and diversity: a critical field of study in global sport management", in Critical Issues in Global Sport Management, Routledge, pp. 31-44.

Giannakis, M. (2011), "Management of service supply chains with a service-oriented reference model: the case of management consulting", Supply Chain Management: An International Journal, Vol. 16 No. 5, pp. 346-361.

Gimenez, C. (2006), "Logistics integration processes in the food industry", International Journal of Physical Distribution \& Logistics Management, Vol. 36 No. 3, pp. 231249. 
Greenwell, T.C., Danzey-Bussell, L.A. and Shonk, D. (2014), Managing sport events, Human Kinetics,

Hall, S., Marciani, L., Cooper, W. and Phillips, J. (2010), "Needs, concerns, and future challenges in security management of NCAA Division I football events: An intercollegiate facility management perspective", Journal of Venue and Event Management, Vol. 1 No. 2, pp. 1-16.

Hall, S.A., Shibli, S. and Schwarz, E. (2010), Sport Facility Operations Management, Routledge,

Heere, B., Wear, H., Jones, A., Breitbarth, T., Xing, X., Paramio Salcines, J.L., . . Derom, I. (2019), "Inducing Destination Images Among International Audiences: The Differing Effects of Promoting Sport Events on the Destination Image of a City Around the World", Journal of Sport Management.

Huyghe, T., Scanlan, A., Dalbo, V. and Calleja-González, J. (2018), "The Negative Influence of Air Travel on Health and Performance in the National Basketball Association: A Narrative Review", Sports, Vol. 6 No. 3, p. 89.

IOC (2017), "IOC Marketing Report for Rio 2016". Retrieved from https://stillmed.olympic.org/media/Document\%20Library/OlympicOrg/Games/Summ er-Games/Games-Rio-2016-Olympic-Games/Media-Guide-for-Rio-2016/IOCMarketing-Report-Rio-2016.pdf

Jenkins, M., Pasternak, K. and West, R. (2016), Performance at the Limit: Business Lessons from Formula 1 Motor Racing, Cambridge University Press,

Jiang, Y. (2008), "Analysis on Beijing Subway flows during the 29th Olympics", Journal of Transportation Systems Engineering and Information Technology, Vol. 8 No. 6, pp. 46-51.

Jones, C. (2012), "Events and festivals: Fit for the future?", Event Management, Vol. 16 No. 2, pp. 107-118. doi:10.3727/152599512X13343565268258

Kassens-Noor, E. (2010), "Sustaining the momentum: Olympics as potential catalyst for enhancing urban transport", Transportation Research Record: Journal of the Transportation Research Board, Vol. No. 2187, pp. 106-113.

Kassens-Noor, E. (2013), "Transport legacy of the Olympic Games, 1992-2012", Journal of Urban Affairs, Vol. 35 No. 4, pp. 393-416.

Kauppi, K., Moxham, C. and Bamford, D. (2013), "Should we try out for the major leagues? A call for research in sport operations management", International Journal of Operations \& Production Management, Vol. 33 No. 10, pp. 1368-1399.

KMPG (2016), "The business of sports - Playing to win as the game unfurls". Retrieved from Geneva, Sitzerland: https://assets.kpmg/content/dam/kpmg/in/pdf/2016/09/thebusiness-of-sports.pdf

Landis, J.R. and Koch, G.G. (1977), "The measurement of observer agreement for categorical data", Biometrics, Vol. 33 No. 1, pp. 159-174.

Light, R. and Pillemer, D.B. (1984), Summing up: The Science of Reviewing Research, Harvard University Press, Cambridge, MA.

Maguire, J. (2000), "Sport and globalization", in Coakey, J. and Dunning, E. (Eds.), Handbook of sports studies, Sage, London, pp. 356-369.

Mahoney, M.P. and McMillen, J.D. (2014), "Facility planning, design, and management of mobility assistance programs: Review and recommendations of accessible routes from super bowl XLV", Journal of Facility Planning, Design, and Management, Vol. 2 No. 2.

Malhado, A. and Araujo, L.M. (2017), "Welcome to Hell: Rio 2016 Olympics Failing to Secure Sustainable Transport Legacy", Event Management, Vol. 21 No. 4, pp. 523526.

Masterman, G. (2014), Strategic sports event management, Routledge, 
McKinnon, A.C. (2013), "Starry-eyed: journal rankings and the future of logistics research", International Journal of Physical Distribution \& Logistics Management, Vol. 43 No. 1, pp. 6-17.

Minis, I., Keys, E. and Athanasopoulos, T. (2006), "Contribution to the design of the Athletes Bus Network during the Athens 2004 Olympic Games", Transportation Research Part A: Policy and Practice, Vol. 40 No. 9, pp. 776-791.

Minis, I., Paraschi, M. and Tzimourtas, A. (2006), "The design of logistics operations for the Olympic Games", International Journal of Physical Distribution \& Logistics Management, Vol. 36 No. 8, pp. 621-642.

Minis, I. and Tsamboulas, D.A. (2008), "Contingency planning and war gaming for the transport operations of the Athens 2004 Olympic Games", Transport Reviews, Vol. 28 No. 2, pp. 259-280.

Morash, E.A., Droge, C.L. and Vickery, S.K. (1996), "Strategic logistics capabilities for competitive advantage and firm success", Journal of Business Logistics, Vol. 17 No. 1, p. 1.

Mulley, C. and Moutou, C.J. (2015), "Not too late to learn from the Sydney Olympics experience: Opportunities offered by multimodality in current transport policy", Cities, Vol. 45 No., pp. 117-122.

O'Mathúna, D.P. (2000), "Evidence-Based Practice and Reviews of Therapeutic Touch", Journal of Nursing Scholarship, Vol. 32 No. 3, pp. 279-285.

Oklobžija, S. (2015), "The role of events in tourism development", Journal of Economics, Management and Informatics, Vol. 6 No. 2, pp. 83-97.

Parent, M.M. and Chappelet, J.-L. (2017), Routledge handbook of sports event management, Routledge,

Pawson, R. (2006), Evidence-based policy: a realist perspective, Sage, London.

Preuss, H. (2007), "The conceptualisation and measurement of mega sport event legacies", Journal of sport \& tourism, Vol. 12 No. 3-4, pp. 207-228.

Preuss, H. (2015), "A framework for identifying the legacies of a mega sport event", Leisure Studies, Vol. 34 No. 6, pp. 643-664.

Robinson, P., Wale, D. and Dickson, G. (2010), Events management, CABI,

Rofe, M.W. and Woosnam, C.L. (2016), "Festivals as a vehicle for place promotion: cars, contestation and the creative city ethos", Landscape Research, Vol. 41 No. 3, pp. 344359.

Rousseau, D.M., Manning, J. and Denyer, D. (2008), "Chapter 11: Evidence in management and organizational science: Assembling the field's full weight of scientific knowledge through syntheses", The Academy of Management Annals, Vol. 2 No. 1, pp. 475-515.

Roy, J. and Forest, G. (2018), "Greater circadian disadvantage during evening games for the National Basketball Association (NBA), National Hockey League (NHL) and National Football League (NFL) teams travelling westward", Journal of Sleep Research, Vol. 27 No. 1, pp. 86-89.

Sandberg, B. and Aarikka-Stenroos, L. (2014), "What makes it so difficult? A systematic review on barriers to radical innovation", Industrial Marketing Management, Vol. 43 No. 8, pp. 1293-1305.

Sant, S.-L. and Mason, D.S. (2015), "Framing event legacy in a prospective host city: Managing Vancouver’s Olympic bid", Journal of Sport Management, Vol. 29 No. 1, pp. 42-56.

Schulenkorf, N. and Frawley, S. (2016), Critical issues in global sport management, Taylor \& Francis, Abingdon.

Schulenkorf, N., Sherry, E. and Rowe, K. (2016), "Sport for development: An integrated literature review", Journal of Sport Management, Vol. 30 No. 1, pp. 22-39. 
Schwarz, E.C., Hunter, J.D. and LaFleuer, A. (2013), Advanced theory and practice in sport marketing, Routledge,

Schwarz, E.C., Westerbeek, H., Liu, D., Emery, P. and Turner, P. (2017), Managing sport facilities and major events, Routledge,

Settimi, C. (2016), "The 2016 Rio Summer Olympics: By The Numbers". Forbes. Retrieved from https://www.forbes.com/sites/christinasettimi/2016/08/05/the-2016-summerolympics-in-rio-by-the-numbers/\#1fdaf07ffa18

Smith, A.D. and Smith, A.A. (2008), "Exploring the service location strategies behind super bowl venue selection", Services Marketing Quarterly, Vol. 29 No. 4, pp. 66-84.

Torraco, R.J. (2005), "Writing Integrative Literature Reviews: Guidelines and Examples", Human Resource Development Review, Vol. 4 No. 3, pp. 356-367.

Tranfield, D., Denyer, D. and Smart, P. (2003), "Towards a methodology for developing evidence-informed management knowledge by means of systematic review", British Journal of Management, Vol. 14 No. 3, pp. 207-222.

Van den Hurk, M. and Verhoest, K. (2017), "On the fast track? Using standard contracts in public-private partnerships for sports facilities: A case study", Sport Management Review, Vol. 20 No. 2, pp. 226-239.

Whisenant, W.A. (2003), "Using biometrics for sport venue management in a post 9-11 era", Facilities, Vol. 21 No. 5/6, pp. 134-141.

Wilson, W. (2015), "Sports infrastructure, legacy and the paradox of the 1984 Olympic Games", The International Journal of the History of Sport, Vol. 32 No. 1, pp. 144156.

Wright, M. (2009), "50 years of OR in sport", Journal of the Operational Research Society, Vol. 60 No. sup1, pp. S161-S168.

Zhou, H., Benton Jr, W., Schilling, D.A. and Milligan, G.W. (2011), "Supply chain integration and the SCOR model", Journal of Business Logistics, Vol. 32 No. 4, pp. 332-344. 